\title{
CALCULATION AND ANALYSIS OF B/T (BURNING AND/OR TRANSMUTATION) RATE OF MINOR ACTINIDES AND PLUTONIUM PERFORMED BY FAST B/T REACTOR
}

\author{
Marsodi \\ Center for Development of Nuclear Informatics \\ National Nuclear Energy Agency (BATAN) - Puspiptek-Serpong,
}

\begin{abstract}
TRANSMUTATION) RATE OF MINOR ACTINIDES AND PLUTONIUM PERFORMED BY FAST B/T REACTOR. Calculation and analysis of B/T (Burning and/or Transmutation) rate of MA (minor actinides) and Pu (Plutonium) has been performed in fast $\mathrm{B} / \mathrm{T}$ reactor. The study was based on the assumption that the spectrum shift of neutron flux to higher side of neutron energy had a potential significance for designing the fast $\mathrm{B} / \mathrm{T}$ reactor and a remarkable effect for increasing the $\mathrm{B} / \mathrm{T}$ rate of MA and/or Pu. The spectrum shifts of neutron have been performed by change MOX to metallic fuel. Blending fraction of MA and or $\mathrm{Pu}$ in $\mathrm{B} / \mathrm{T}$ fuel and the volume ratio of fuel to coolant in the reactor core were also considered. Here, the performance of fast $\mathrm{B} / \mathrm{T}$ reactor was evaluated theoretically based on the calculation results of the neutronics and burn-up analysis. In this study, the B/T rate of MA and/or Pu increased by increasing the blending fraction of MA and or $\mathrm{Pu}$ and by changing the $\mathrm{F} / \mathrm{C}$ ratio. According to the results, the total $\mathrm{B} / \mathrm{T}$ rate, i.e. $[\mathrm{B} / \mathrm{T} \text { rate }]_{\mathrm{MA}}+[\mathrm{B} / \mathrm{T} \text { rate }]_{\mathrm{Pu}}$, could be kept nearly constant under the critical condition, if the sum of the MA and Pu inventory in the core is nearly constant. The effect of loading structure was examined for inner or outer loading of concentric geometry and for homogeneous loading. Homogeneous loading of B/T fuel was the good structure for obtaining the higher $\mathrm{B} / \mathrm{T}$ rate, rather than inner or outer loading.
\end{abstract}

Keywords: HLW, Waste management, Burning/Transmutation, Fast reactor, Spectrum shift, and Neutron flux.

\section{ITRODUCTION}

The concept for burning and/or transmutation of minor actinides was developed to realize the $\mathrm{B} / \mathrm{T}$ (Burning and/or Transmutation) performance for changing the long-lived radio nuclides into the short-lived ones by neutron reaction in the spectrum hardened fast $\mathrm{B} / \mathrm{T}$ reactor, thought the specifications of fast $\mathrm{B} / \mathrm{T}$ reactor were assumed to be similar to the fast reactor listed elsewhere [1,2]. The potentiality for fast $\mathrm{B} / \mathrm{T}$ treatment of the energy spectrum shift in the fast region and the considerations of MA loading pattern in the reactor core was focused here for getting higher performance of fast $\mathrm{B} / \mathrm{T}$ reactor.

A survey with respect to the core structure which was loaded with $\mathrm{B} / \mathrm{T}$ fuel was reported by PNC group and another survey with respect to the advanced fast burning reactor (ABR) cooled with He gas by Mukaeyama [3], and the performance of $\mathrm{B} / \mathrm{T}-\mathrm{PWR}$ loaded with $\mathrm{UO}_{2}$ was compared with MOX fueled B/T-PWR and high convection reactor by Takano [4] of JAERI group. The properties of hard-spectrum actinides fission reactors with metal fuel in 
EBR II was studied by Thompson et al [5] of ANL group. The properties of fast $\mathrm{B} / \mathrm{T}$ reactor loaded with vibropac polydispersive fuel (VMOX) were studied up to super-high burn-up (20-25\%) by the research groups of RIAR (Russia). Some studies mentioned above discussed the characteristics of fast $\mathrm{B} / \mathrm{T}$ treatment as mentioned by Advanced Reactor design Team in JAERI [6], however, it was not possible to find the study, which examined the relation between the neutron spectrum shift in fast $\mathrm{B} / \mathrm{T}$ reactor and the increase of the $\mathrm{B} / \mathrm{T}$ rate or the capacity in $\mathrm{B} / \mathrm{T}$ treatment.

$\mathrm{A}$ fast $\mathrm{B} / \mathrm{T}$ reactor should be designed and performed to realize the maximum of $\mathrm{B} / \mathrm{T}$ rate of MA, LLFPs (long-lived fission product) and/or $\mathrm{Pu}$ by neutron reaction as studied by Wakabayashi [7]. It is important that the $\mathrm{B} / \mathrm{T}$ rate of MA, LLFPs and/or Pu, the annihilation rate of them, should be far larger than their production rate by fission reaction. The neutron economy is also another important factor to keep the high $\mathrm{B} / \mathrm{T}$ rate. In this study, the concept of "Hard Spectrum Fast B/T Reactor" was developed to realize the maximum of $\mathrm{B} / \mathrm{T}$ rate of $\mathrm{MA}$, and/or $\mathrm{Pu}$ with the neutron spectrum shift to the higher energy side, i.e. higher than $1 \mathrm{MeV}$. In this cases, the fission crosssection of MA in the higher energy region, i.e. En $>0.1 \mathrm{MeV}$ was 60 to 100 times larger than the fission cross section in the energy region, i.e. $0.6 \mathrm{MeV}>\mathrm{En}>0.1 \mathrm{MeV}$. The while, the ordinary fast reactor for energy production had a maximum value of the neutron flux spectrum.

The purpose of this study is to examine the potential merits of the spectrum shifted fast reactor for $\mathrm{B} / \mathrm{T}$ treatment, in order to obtain the maximum $\mathrm{B} / \mathrm{T}$ rate and the $\mathrm{B} / \mathrm{T}$ capacity. Moreover, it is also to know how to determine the loading pattern of MA and/or $\mathrm{Pu}$ in limited reactor core, with the variation of the blending fraction of $\mathrm{MA}$ and/or $\mathrm{Pu}$ in $\mathrm{B} / \mathrm{T}$ fuel, and the $\mathrm{F} / \mathrm{C}$ ratio, i.e. the volume ratio of fuel to coolant. This study is also dedicated to establish a new concept of $\mathrm{B} / \mathrm{T}$ reactor. The calculation of the results has been done using modified code program developed by Bandung Institute of Technology, ITB, and using the Chain Reaction Code Program for calculating the mass balance.

\section{NUMERICAL PROCEDURES}

The characteristics of a similar $3 \mathrm{Gwt}$ Fast $\mathrm{B} / \mathrm{T}$ reactor loaded with metal type B/T fuel, U-Pu-MA-Zr $10 \mathrm{w} \%$, were compared with 3 Gwt Fast $\mathrm{B} / \mathrm{T}$ reactor loaded with $\mathrm{MOX}$ type $\mathrm{B} / \mathrm{T}$ fuel, $\left(\mathrm{UO}_{2}-\mathrm{PuO}_{2}-\mathrm{MAO}_{2}\right)$. The $\mathrm{B} / \mathrm{T}$ rate in fast reactor was estimated by solving the multi-group diffusion equations with homogeneous or two regional loading of MA and/or Pu. The conceptual details and the neutron utilization in the fast $\mathrm{B} / \mathrm{T}$ reactor were evaluated numerically by the model of one-dimensional, 26-group neutron diffusion equations for concentric cylindrical geometry. The conditions supposed in the model are shown in Table 1. 
Table 1. Parameters used in the conceptual model of fast $\mathrm{B} / \mathrm{T}$ reactor loaded with oxide or metallic fuel.

\begin{tabular}{|c|c|}
\hline Design Parameter & Specification \\
\hline Reactor power & $3 \mathrm{GWt}$ \\
\hline Core geometry & Cylindrical \\
\hline Equivalent height & $100 \mathrm{~cm}$ \\
\hline Equivalent diameter & $400 \mathrm{~cm}$ \\
\hline \multicolumn{2}{|l|}{ Fuel } \\
\hline $\begin{array}{l}\text { Chemical form of fuel type } \\
\text { Isotopic composition }\end{array}$ & $\begin{array}{l}\mathrm{U}-\mathrm{Pu} \mathrm{O}_{2}-\mathrm{MA} \mathrm{O}_{2} \text {, U-PU-MA-Zr } 10 \mathrm{w} \% \\
\text { Standard composition equivalent to the } \\
\text { discharged fuel from } 33 \mathrm{GWd} / \mathrm{Mg}(\mathrm{HM}) \text { - } \\
\mathrm{LWR}, 150 \text { days cooling }\end{array}$ \\
\hline Materials of coolant & Sodium \\
\hline Group energy & 26-group \\
\hline Average Neutron flux & $471 \mathrm{E}+14\left(\mathrm{n} / \mathrm{cm}^{2} \mathrm{~s}\right)$ \\
\hline Average Neutron Energy & $1.3465 \mathrm{E}+05(\mathrm{eV})$ \\
\hline Chain reaction for TRU & $\begin{array}{l}\text { Isotopic chain reaction for } \mathrm{U}, \mathrm{Np}, \mathrm{Pu}, \mathrm{Am} \text {, } \\
\mathrm{Cm}, \mathrm{Bk}, \mathrm{Cf} \text {, and } \mathrm{Cs} \text { by }(\mathrm{n}, \alpha),(\mathrm{n}, \beta),(\mathrm{n}, \gamma) \\
\text { etc. }\end{array}$ \\
\hline
\end{tabular}

The 26-group effective nuclear cross sections, $\sigma^{\mathrm{g}}$, for $\mathrm{U}, \mathrm{Pu}$, and MA and also for main component of FPs was selected from 26-group data reported by Bondarenko and BNL cross section data [8,9], as described in Table 1 . The capacity $(\mathrm{kg})$ of $\mathrm{B} / \mathrm{T}$ reactor was defined by the total mass of $\mathrm{MA}$ isotopes loaded into fast $\mathrm{B} / \mathrm{T}$ reactor. The $\mathrm{B} / \mathrm{T}$ rate $(\mathrm{kg} / \mathrm{y})$ was defined by the total quantity of MA burned and/or transmuted per one year to short-lived radionuclides.

The behavior of the atomic density of MA and/or $\mathrm{Pu}, \mathrm{Ni}(\mathrm{t})$, can be estimated by the M-simultaneous differential equations defined by Eq. (1):

$$
\begin{gathered}
\left(\mathrm{dN}_{\mathrm{i}}(\mathrm{t}) / \mathrm{dt}\right)=\Sigma_{\mathrm{j}} \mathrm{l}_{\mathrm{ij}} \lambda_{\mathrm{i}} \mathrm{N}_{\mathrm{j}}+\sum_{\mathrm{g}} \phi^{\mathrm{g}} \sum_{\mathrm{k}} \mathrm{f}_{\mathrm{ik}}\left(\sigma_{\mathrm{k}}^{\mathrm{g}} \mathrm{N}_{\mathrm{k}}-\left(\lambda_{\mathrm{i}}+\Sigma_{\mathrm{g}} \phi^{\mathrm{g}} \sigma_{\mathrm{i}}^{\mathrm{g}}\right) \mathrm{N}_{\mathrm{i}}\right. \\
(\mathrm{i}, \mathrm{j}, \mathrm{k}=1,2, \ldots ., \mathrm{M}),(\mathrm{g}=1,2, \ldots . . \mathrm{Ng})
\end{gathered}
$$

where $\mathrm{N}_{\mathrm{i}}(\mathrm{t})$ for the inner loading $\left(0 \leq \mathrm{r} \leq \mathrm{R}_{\mathrm{s}}\right)$ of $\mathrm{B} / \mathrm{T}$ fuel, as shown in Fig. 1, is given by

$$
\begin{array}{lc}
N_{i}(t)=N_{i}^{I F}(t)+N_{i}^{I B T}(t) & \left(0 \leq r \leq R_{s}\right) \\
N_{i}(t)=N_{i}^{O F}(t), N_{i}^{\text {OBT }}(t)=0 & \left(R_{s} \leq r \leq R_{o}\right)
\end{array}
$$


Here, $\sigma_{\mathrm{k}}{ }^{\mathrm{g}}$ means the total cross section for absorption, which included the reaction of $(n, f),(n, \gamma),(n, \beta),(n, \alpha)$, and $(n, n)$, etc., and the fraction of the reactions, $\mathrm{f}_{\mathrm{ik}} \sigma_{\mathrm{k}}{ }^{\mathrm{g}}$ and $\mathrm{l}_{\mathrm{ij}} \sigma_{\mathrm{k}}{ }^{\mathrm{g}}$ were distinguished by the coefficients, such as $\mathrm{f}_{\mathrm{ik}}$ and $\mathrm{l}_{\mathrm{ij}}$, in the chain reaction schemes and tables etc. In the calculation, the cross section for reaction of $(n, 2 n),(n, 3 n)$, or $(n, p)$ was not included, because those are too small as compared with the cross section of (n,n).

At the initial state $\mathrm{N}_{\mathrm{i}}^{\mathrm{IF}}, \mathrm{N}_{\mathrm{i}}^{\mathrm{IBT}}, \mathrm{N}_{\mathrm{i}}^{\mathrm{OF}}, \mathrm{N}_{\mathrm{i}}^{\mathrm{OBT}}$ were assumed to be constant in the defined region, respectively. MA means MA and $\mathrm{U} \& \mathrm{Pu}$. U\&Pu, or $\mathrm{U}$ and $\mathrm{Pu}$, considered here means the unrecovered $\mathrm{U}$ and $\mathrm{Pu}$ remained in HLW after reprocessing. The element included in $\mathrm{MA}^{*}$ ) are $\mathrm{Np}, \mathrm{Am}, \mathrm{Cm}, \mathrm{U}$, and $\mathrm{Pu} . \mathrm{M}$ is the total number of isotopes in $\mathrm{MA}, \mathrm{U}$ and $\mathrm{Pu}$ taken into the chain reaction of the model. The model was composed of the isotopes more than 50 , i.e. the isotopes for $\mathrm{U}, \mathrm{Np}, \mathrm{Pu}, \mathrm{AM}, \mathrm{Cm}, \mathrm{Bk}, \mathrm{Cf}$, and Es.

(1) Inner loading ，

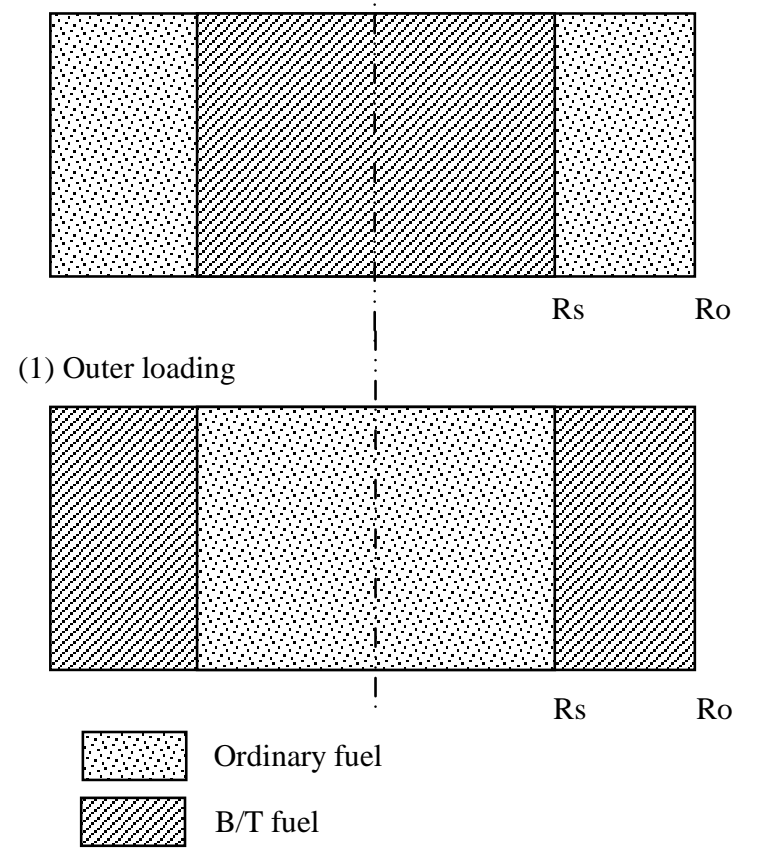

Fig. 1. Schematic loading structure of $\mathrm{B} / \mathrm{T}$ fuel (inner loading, and outer loading).

The time $\mathrm{t}$ was defined in the period from 0 to $\tau, \tau$ be the cycle period under consideration. Generally speaking, the cycle period is shorter than the recycle period. The former is equal to the latter, the waiting of the storage time for mass in the out-core loop (i.e. the time required to treat in the reprocessing and/or partitioning process) is assumed to be zero. The word "cycle" was used to describe the reactor behavior, and was distinguished with 
the word "recycle", which was used to describe the mass balance in $\mathrm{B} / \mathrm{T}$ reactor, including the additive mass, derived from the out-core loop.

Schematic structure of $\mathrm{B} / \mathrm{T}$ fuel loaded into the outer region $(0 \leq \mathrm{r} \leq$ $R_{s}$ ) is shown in Fig. 1. $N_{i}(t)$ for the outer loading of $B / T$ fuel can be given by

$$
\begin{array}{ll}
\mathrm{N}_{\mathrm{i}}(\mathrm{t})=\mathrm{N}_{\mathrm{i}}^{\mathrm{IF}}(\mathrm{t}), \mathrm{N}_{\mathrm{i}}^{\mathrm{IBT}}(\mathrm{t})=0 & \left(0 \leq \mathrm{r} \leq \mathrm{R}_{\mathrm{s}}\right) \\
\mathrm{N}_{\mathrm{i}}(\mathrm{t})=\mathrm{N}_{\mathrm{i}}^{\mathrm{OF}}(\mathrm{t})+\mathrm{N}_{\mathrm{i}}^{\mathrm{OBT}}(\mathrm{t}) & \left(\mathrm{R}_{\mathrm{s}} \leq \mathrm{r} \leq \mathrm{R}_{\mathrm{o}}\right)
\end{array}
$$

Eq. (6) and (7) as shown in Fig. 1 defined the space average of neutron flux $\phi^{\mathrm{g}}(\mathrm{r})$.

$$
\begin{aligned}
& \phi^{\mathrm{g}}=\left\{1 /\left(\pi \mathrm{R}_{\mathrm{s}}{ }^{2}\right)\right\}\left(\Delta \mathrm{u}^{\mathrm{g}} / \Sigma_{\mathrm{g}} \Delta \mathrm{u}^{\mathrm{g}}\right) f_{\mathrm{o}}^{\mathrm{Rs}} 2 \pi \mathrm{r} \phi^{\mathrm{g}}(\mathrm{r}) \mathrm{dr} \quad\left(0 \leq \mathrm{r} \leq \mathrm{R}_{\mathrm{s}}\right) \\
& \phi^{\mathrm{g}}=1 /\left\{\pi\left(\mathrm{R}_{\mathrm{o}}{ }^{2}-\mathrm{R}_{\mathrm{s}}{ }^{2}\right)\right\}\left(\Delta \mathrm{u}^{\mathrm{g}} / \Sigma_{\mathrm{g}} \Delta \mathrm{u}^{\mathrm{g}}\right) f_{\mathrm{Rs}}^{\mathrm{Rs}} 2 \pi \mathrm{r} \phi^{\mathrm{g}}(\mathrm{r}) \mathrm{dr} \quad\left(\mathrm{R}_{\mathrm{s}} \leq \mathrm{r} \leq \mathrm{R}_{\mathrm{o}}\right)
\end{aligned}
$$

where the local neutron flux $\phi^{\mathrm{g}}(\mathrm{r})\left(\mathrm{n} / \mathrm{cm}^{2} \mathrm{~s}\right)$ of group-g $(\mathrm{g}=1,2, \ldots$, $\mathrm{N}_{\mathrm{g}}$ ) could be given by a set of multi-group diffusion equation of neutron under the critical condition, with the boundary conditions given by Eqs. (2) and (3) for inner loading, or with the boundary conditions given by Eqs. (4) and (5) for outer loading. $\Sigma_{\mathrm{g}}$ in Eqs. (6) and (7) means the summation of $\Delta \mathrm{u}^{\mathrm{g}}$.

Here the total inventory of MA, [INV] (t), was defined by

$$
\begin{aligned}
{[\mathrm{INV}](\mathrm{t})=(} & \left.\mathrm{M}_{\mathrm{i}} / \mathrm{N}_{\mathrm{A}}\right)\left[\left(\left(\mathrm{R}_{\mathrm{s} 2} \mathrm{~h}\right) \Sigma_{\mathrm{i}}\left\{\mathrm{N}_{\mathrm{i}}^{\mathrm{IF}}(\mathrm{t})+\mathrm{N}_{\mathrm{i}}^{\mathrm{IBT}}(\mathrm{t})\right\}+\right.\right. \\
& \left.\left\{\left(\pi \mathrm{R}_{\mathrm{o}}^{2}-\mathrm{R}_{\mathrm{s}}^{2}\right) \mathrm{h}\right\} \Sigma_{\mathrm{i}}\left\{\mathrm{N}_{\mathrm{i}}^{\mathrm{OF}}(\mathrm{t})+\mathrm{N}_{\mathrm{i}}^{\mathrm{OBT}}(\mathrm{t})\right\}\right] \\
& (\mathrm{i}=1,2, \ldots ., \mathrm{M})
\end{aligned}
$$

where $\mathrm{N}_{\mathrm{i}}(\mathrm{t})$ is the atomic density of $\mathrm{MA}$ and/or $\mathrm{Pu}$ in the inner region $\left(0 \leq r \leq R_{s}\right)$ and in the outer region $\left(R_{s} \leq r \leq R_{o}\right)$. equation.

The total gain for inner loading was evaluated by the following

$$
[\mathrm{B} / \mathrm{T} \text { rate }]_{\mathrm{t}}=\Sigma_{\mathrm{g}}[\mathrm{B} / \mathrm{T} \text { rate }]_{\mathrm{g}} \Delta \mathrm{u}_{\mathrm{g}} / \Sigma_{\mathrm{g}} \Delta \mathrm{u}_{\mathrm{g}}
$$

where $[\mathrm{B} / \mathrm{T} \text { rate }]_{\mathrm{g}}=\left(\pi \mathrm{R}_{\mathrm{s}}{ }^{2} \mathrm{~h}\right) \Sigma_{\mathrm{i}}\left(\mathrm{M}_{\mathrm{i}} / \mathrm{N}_{\mathrm{A}}\right)\left(\mathrm{dN}_{\mathrm{i}}^{\mathrm{IBT}} / \mathrm{dt}\right)_{\mathrm{g}}$

$$
\begin{array}{r}
\left(\mathrm{dN}_{\mathrm{i}}^{\mathrm{IBT}} / \mathrm{dt}\right)_{\mathrm{g}}=\Sigma_{\mathrm{j}} \mathrm{l}_{\mathrm{ij}} \lambda_{\mathrm{j}} \mathrm{N}_{\mathrm{j}}+\phi^{\mathrm{g}} \sum_{\mathrm{k}} \mathrm{f}_{\mathrm{ik}} \sigma_{\mathrm{k}}^{\mathrm{g}} \mathrm{N}_{\mathrm{k}}-\left(\lambda_{\mathrm{i}}+\phi^{\mathrm{g}} \sigma_{\mathrm{i}}^{\mathrm{g}}\right) \mathrm{N}_{\mathrm{i}} \\
(\mathrm{i}, \mathrm{j}, \mathrm{k}=1,2, \ldots ., \mathrm{M}),(\mathrm{g}=1,2, \ldots . . \mathrm{Ng})
\end{array}
$$

The instantaneous $\mathrm{B} / \mathrm{T}$ rate, $[\mathrm{B} / \mathrm{T}$ rate $](\mathrm{t})$, and the time averaged $\mathrm{B} / \mathrm{T}$ rate, $[\mathrm{B} / \mathrm{T} \text { rate }]_{\mathrm{av}}$, for inner loading were defined by the equation,

$$
\begin{aligned}
& {[\mathrm{B} / \mathrm{T} \text { rate }]_{\mathrm{g}}=\left(\pi \mathrm{R}_{\mathrm{s}}{ }^{2} \mathrm{~h}\right) \Sigma_{\mathrm{i}}\left(\mathrm{M}_{\mathrm{i}} / \mathrm{N}_{\mathrm{A}}\right)\left(\mathrm{dN}_{\mathrm{i}}^{\mathrm{IBT}} / \mathrm{dt}\right)_{\mathrm{g}}} \\
& {[\mathrm{B} / \mathrm{T} \text { rate }]_{\mathrm{av}}=\left(\pi \mathrm{R}_{\mathrm{s}}{ }^{2} \mathrm{~h}\right)} \\
& \Sigma_{\mathrm{i}}\left(\mathrm{M}_{\mathrm{i}} / \mathrm{N}_{\mathrm{A}}\right)\left(\mathrm{N}_{\mathrm{i}}^{\mathrm{IBT}}(0)-\mathrm{N}_{\mathrm{i}}^{\mathrm{IBT}}(\tau)\right\} / \tau \\
& (\mathrm{i}=1,2, \ldots ., \mathrm{M})
\end{aligned}
$$

The capacity $\left[\mathrm{C}_{\mathrm{p}}\right]$ for the standard composition is defined by $[\mathrm{INV}](\mathrm{t}=0)$,

$$
\left[\mathrm{C}_{\mathrm{p}}\right]=[\mathrm{INV}](\mathrm{t}=0)
$$


In case of outer loading of B/T fuel, Eq. (10) to Eq. (13) should be defined again by a similar relation, under the substitution of the constant $\left\{\pi\left(R_{\mathrm{o}}{ }^{2}-\mathrm{R}_{\mathrm{s}}{ }^{2}\right) \mathrm{h}\right\}$ instead of $\left(\pi \mathrm{R}_{\mathrm{s}}{ }^{2} \mathrm{~h}\right)$ and also the substitution of the variable $\mathrm{N}_{\mathrm{i}}^{\mathrm{OBT}}$ instead of $\mathrm{N}_{\mathrm{i}}^{\mathrm{IBT}}$ in those relations, respectively.

The total mass of MA and/or Pu produced by U-Pu fuel, [P], during the cycle $\tau$ can be estimated by Eq. (15),

$$
[\mathrm{P}]=\left(\mathrm{M}_{\mathrm{i}} / \mathrm{N}_{\mathrm{A}}\right)\left[\left(\pi \mathrm{R}_{\mathrm{s}}^{2} \mathrm{~h}\right) \Sigma_{\mathrm{i}} \mathrm{N}_{\mathrm{i}}^{\mathrm{IF}}(\tau)+\left\{\left[\left(\pi \mathrm{R}_{\mathrm{o}}^{2}-\mathrm{R}_{\mathrm{s}}^{2}\right) \mathrm{h}\right\} \Sigma_{\mathrm{i}} \mathrm{N}_{\mathrm{i}}^{\mathrm{OF}}(\tau)\right.\right.
$$

where $\mathrm{N}_{\mathrm{i}}^{\mathrm{IF}}(\tau)$ and $\mathrm{N}_{\mathrm{i}}^{\mathrm{OF}}(\tau)$ are the atomic density at the end of cycle $\tau$, in the inner and the outer region, respectively. The $\mathrm{B} / \mathrm{T}$ process was evaluated by some factors, such as $[\mathrm{B} / \mathrm{T} \text { rate }]_{\mathrm{av}},[\mathrm{B} / \mathrm{T} \text { rate }]_{\mathrm{t}},[\mathrm{B} / \mathrm{T}$ rate $]$ and $[\mathrm{P}]$, or the combined factors, such as $[\mathrm{B} / \mathrm{T}$ rate $] /[\mathrm{P}],[\mathrm{B} / \mathrm{T} \text { rate }]_{\mathrm{t}} /[\mathrm{P}],([\mathrm{B} / \mathrm{T}$ rate $]-[\mathrm{P}]) /$ $[\mathrm{P}]$ etc.

The burning and/or transmutation rates and the accumulation of MA in the depletion calculation, given by a set of M-simultaneous differential equations defined by Eq.(1) (for $\mathrm{i}=1,2, \ldots ., \mathrm{M}$ ), could be obtained numerically by the Runge-Kutta-Gill method, by using the space averaged neutron fluxes defined by Eq.(6) and (7) which can be estimated from g-grouped neutron fluxes, after g-grouped neutron flux distributions were given by the multi-group critical equation, respectively[1,8,9]. The build up chain reactions of in MA isotopes were considered here for uranium and transuranic isotopes i.e. $\mathrm{U}, \mathrm{Np}, \mathrm{Pu}, \mathrm{Am}, \mathrm{Cm}, \mathrm{Bk}, \mathrm{Cf}$, and Es. In this computation, the mesh $\Delta \mathrm{t}$ in t-axis i.e. the time interval was fixed at 10 minutes, which was the order of the shortest half-life of radionuclide in the calculation analysis.

The effect of neutron spectrum shift on the fast $\mathrm{B} / \mathrm{T}$ reactor was evaluated based on the standard isotopic composition of MA in HLW included in discharged fuel from $1 \mathrm{GWe}-\mathrm{LWR}$, under the burn up of 33,000 MWd/MgHM (Heavy Metal) with the cooling time of 150 days. The initial condition of isotopic composition and the mass quantity of $\mathrm{MA}$, and $\mathrm{U} \& \mathrm{Pu}$ used In the calculation analysis of $\mathrm{B} / \mathrm{T}$ treatment are shown in Table 2. 
Table 2. Isotopes and standard composition of discharged fuel from $33 \mathrm{GWd} / \mathrm{Mg}(\mathrm{HM})-\mathrm{LWR}, 150$ days cooling used in the calculations.

\begin{tabular}{|c|c|c|c|c|}
\hline Nuclide & $\begin{array}{c}\text { Half-life } \\
(\mathrm{yr})\end{array}$ & $\begin{array}{c}\text { Atomic } \\
\text { fraction (-) }\end{array}$ & $\begin{array}{c}\text { TRU } \\
\text { fraction (-) }\end{array}$ & \begin{tabular}{|c}
$\begin{array}{c}\text { Discharged rate } \\
(\mathrm{kg} / \mathrm{y})\end{array}$ \\
\end{tabular} \\
\hline $\begin{array}{l}\mathrm{U}-235 \\
\mathrm{U}-238 \\
\mathrm{U}-234,236, \\
237\end{array}$ & $\begin{array}{l}7.10 \mathrm{E}+08 \\
2.57 \mathrm{E}+08\end{array}$ & $\begin{array}{l}0.008 \\
0.988 \\
0.004\end{array}$ & 0.98090 & $\begin{array}{l}2.15 \mathrm{E}+02 \\
2.57 \mathrm{E}+04 \\
9.46 \mathrm{E}+01 \\
2.59 \mathrm{E}+04\end{array}$ \\
\hline $\begin{array}{l}\mathrm{Pu}-239 \\
\mathrm{Pu}-240 \\
\mathrm{Pu}-241 \\
\mathrm{Pu}-242\end{array}$ & $\begin{array}{l}2.40 \mathrm{E}+04 \\
6.58 \mathrm{E}+03 \\
1.32 \mathrm{E}+02 \\
3.79 \mathrm{E}+02\end{array}$ & $\begin{array}{l}0.625 \\
0.215 \\
0.110 \\
0.050\end{array}$ & 0.01730 & $\begin{array}{l}1.44 \mathrm{E}+02 \\
5.91 \mathrm{E}+01 \\
2.77 \mathrm{E}+01 \\
9.65 \mathrm{E}+00 \\
2.39 \mathrm{E}+02\end{array}$ \\
\hline $\begin{array}{l}\text { Np-237 } \\
\text { Np-241 } \\
\text { Np-243 } \\
\text { Np-244 }\end{array}$ & $\begin{array}{l}2.14 \mathrm{E}+06 \\
4.58 \mathrm{E}+02 \\
7.95 \mathrm{E}+03 \\
1.76 \mathrm{E}+02\end{array}$ & $\begin{array}{l}0.816 \\
0.052 \\
0.097 \\
0.035\end{array}$ & 0.002326 & $\begin{array}{c}2.04 \mathrm{E}+00 \\
1.32 \mathrm{E}+00 \\
2.48 \mathrm{E}+00 \\
9.11 \mathrm{E}-01 \\
2.51 \mathrm{E}+01\end{array}$ \\
\hline
\end{tabular}

\section{RESULTS AND DISCUSSION}

Basic design parameters for fast $\mathrm{B} / \mathrm{T}$ reactor with no blankets, but with reflectors, were studied in order to estimate the $\mathrm{B} / \mathrm{T}$ characteristics, the $\mathrm{B} / \mathrm{T}$ rate and the capacity of MA. Here, the blanket has not so much significant role in the calculation analysis of $\mathrm{B} / \mathrm{T}$ characteristics, so the reactor core surrounded only by the reflector. As the fission cross section of TRU isotopes in the energy region higher than $1 \mathrm{MeV}$ becomes large value, the spectrum shifted fast $\mathrm{B} / \mathrm{T}$ reactor seemed to have a meaningful concept to obtain $\mathrm{B} / \mathrm{T}$ rate. The initial component of $\mathrm{MA}$ loaded into $\mathrm{B} / \mathrm{T}$ reactor was supposed to be ${ }^{237} \mathrm{~Np},{ }^{241} \mathrm{Am},{ }^{243} \mathrm{Am}$, and ${ }^{244} \mathrm{Cm}$, which were the components of MA contained in the discharged fuel from LWR at the burn-up of $33,000 \mathrm{MWd} / \mathrm{Mg}(\mathrm{HM})$. The chain reactions of the isotopes of $U$ and TRU during $\mathrm{B} / \mathrm{T}$ treatment were taken into the calculation analysis, i.e. $\mathrm{U}, \mathrm{Np}, \mathrm{Pu}$, $\mathrm{Am}, \mathrm{Cm}, \mathrm{Bk}, \mathrm{Cf}$, and Es. 


\section{Effect of fuel type on the $B / T$ rate}

The characteristics of fast $\mathrm{B} / \mathrm{T}$ reactor loaded with $\mathrm{MOX}$ fuel, $\left(\mathrm{UO}_{2^{-}}\right.$ $\mathrm{PuO}_{2}-\mathrm{MAO}_{2}$ ), were compared with the metal fuel blended with $\mathrm{MA}$, U-PuMA-Zr $10 \mathrm{w} \%$. Both reactors loaded with MOX or metal fuel were kept at the same conditions, i.e. $(\mathrm{F} / \mathrm{C})=(0.325 / 0.455)(-),[\mathrm{Pu}]=0.25(-)$, and $[\mathrm{MA}]=0.10(-)$. The relation between neutron flux (and neutron energy En is shown in Fig. 2.(a), the relation between $\mathrm{B} / \mathrm{T}$ rate of MA and neutron energy En is shown in Fig. 2(b) and the relation between $\mathrm{B} / \mathrm{T}$ rate of $\mathrm{Pu}$ and neutron energy En is shown in Fig. 2(c). Those reactors were loaded with metal fuel U-Pu-MA-Zr $10 \mathrm{w} \%$ or oxide fuel $\left(\mathrm{UO}_{2}-\mathrm{PuO}_{2}-\mathrm{MAO}_{2}\right)$, under the volume fraction of $(\mathrm{F} / \mathrm{C} / \mathrm{S})=(0.325 / 0.455 / 0.220)(-)$.

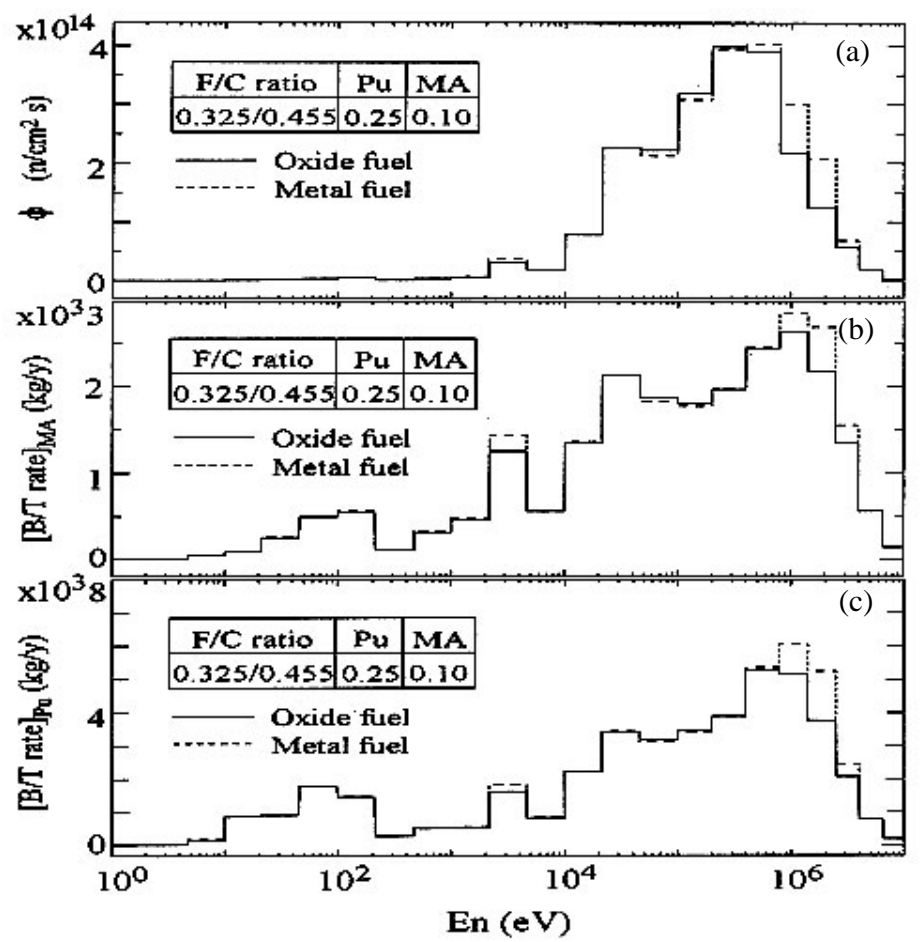

Fig. 2. (a) Relation between neutron flux and neutron energy En, (b) relation between $[\mathrm{B} / \mathrm{T} \text { rate }]_{\mathrm{MA}}$, and $\mathrm{En}$, and (c) relation between $[\mathrm{B} / \mathrm{T} \text { rate }]_{\mathrm{Pu}}$, and $\mathrm{En}$, for fast $\mathrm{B} / \mathrm{T}$ reactor loaded with metallic (U-Pu-MA-Zr) and oxide $\left(\mathrm{UO}_{2}-\mathrm{PUO}_{2}-\mathrm{MAO}_{2}\right)$ fuel, $(\mathrm{F} / \mathrm{C} / \mathrm{S})=(0.325 / 0.455 / 0.220)$.

According to the results seen in Fig. 2(a) to 2(c), the spectrum shift was clearly seen at 6 and 7-th energy groups counted from the top MeVenergy group. The $\mathrm{B} / \mathrm{T}$ rate gain of MA was improved considerably by the metal fuel reactor. The metal fuel could improve the $\mathrm{B} / \mathrm{T}$ rate gain of $\mathrm{Pu}$, too, 
in the range higher than $1 \mathrm{MeV}$, as seen in Fig. 2(c). So, the spectrum shift of the neutron flux caused by the metallic $\mathrm{B} / \mathrm{T}$ fuel has a potential significance to obtain the higher $\mathrm{B} / \mathrm{T}$ rate of $\mathrm{MA}$ and/or $\mathrm{Pu}$.

\section{Loading structure of $B / T$ fuel}

The effectiveness of loading structure of $\mathrm{B} / \mathrm{T}$ fuel in the reactor core was evaluated under the critical condition. Here, the effect of loading structure was examined only for metallic fuel fast $\mathrm{B} / \mathrm{T}$ reactor, because the characteristics with MOX fuel were quite similar to those with metallic $\mathrm{B} / \mathrm{T}$ fuel.

Table 3. Relation of $[\mathrm{B} / \mathrm{T} \text { rate }]_{\mathrm{MA}},[\mathrm{INV}]_{\mathrm{MA}},[\mathrm{B} / \mathrm{T} \text { rate }]_{\mathrm{MA}} /[\mathrm{INV}]_{\mathrm{MA}}$ and $\phi_{\mathrm{av}}$. For inner and outer loading, with respect to (Rs/Ro).

(1)For inner loading

\begin{tabular}{|c|c|c|c|c|}
\hline $\begin{array}{c}\mathrm{R}_{\mathrm{s}} / \mathrm{R}_{\mathrm{o}} \\
(-)\end{array}$ & $\begin{array}{c}{[\mathrm{B} / \mathrm{T} \mathrm{rate}]_{\mathrm{MA}}} \\
(\mathrm{kg})\end{array}$ & $\begin{array}{c}{[\mathrm{INV}]_{\mathrm{MA}}} \\
(\mathrm{kg})\end{array}$ & $\begin{array}{c}{[\mathrm{B} / \mathrm{T} \text { rate }]_{\mathrm{MA}}} \\
/[\mathrm{INV}]_{\mathrm{MA}} \\
(\mathrm{kg})\end{array}$ & $\begin{array}{c}\phi_{\mathrm{av}} \\
\left(\mathrm{n} / \mathrm{cm}^{2} \mathrm{~s}\right)\end{array}$ \\
\hline & & & & \\
1.0 & 9.44 & 4944.0 & 0.191 & $4.71 \mathrm{E}+14$ \\
0.8 & 621.06 & 3164.1 & 0.193 & $5.03 \mathrm{E}+14$ \\
0.6 & 422.02 & 1780.8 & 0.237 & $5.45 \mathrm{E}+14$ \\
0.4 & 225.11 & 791.0 & 0.285 & $6.41 \mathrm{E}+14$ \\
0.2 & 80.51 & 197.8 & 0.407 & $7.00 \mathrm{E}+14$ \\
0.0 & 0.00 & 0.0 & - & - \\
& & & & \\
\hline
\end{tabular}

(1)For outer loading

\begin{tabular}{|c|c|c|c|c|}
\hline $\begin{array}{c}\mathrm{R}_{\mathrm{s}} / \mathrm{R}_{\mathrm{o}} \\
(-)\end{array}$ & $\begin{array}{c}{\left[\mathrm{B} / \mathrm{T} \mathrm{rate}_{\mathrm{MA}}\right.} \\
(\mathrm{kg})\end{array}$ & $\begin{array}{c}{[\mathrm{INV}]_{\mathrm{MA}}} \\
(\mathrm{kg})\end{array}$ & $\begin{array}{c}{\left[\mathrm{B} / \mathrm{T} \mathrm{rate}_{\mathrm{MA}}\right.} \\
/[\mathrm{INV}]_{\mathrm{MA}} \\
(\mathrm{kg})\end{array}$ & $\begin{array}{c}\phi_{\mathrm{av}} \\
\left(\mathrm{n} / \mathrm{cm}^{2} \mathrm{~s}\right)\end{array}$ \\
\hline & & & & - \\
1.0 & 0.00 & 0.00 & - & $-25 \mathrm{E}+14$ \\
0.8 & 19.02 & 1779.8 & 0.067 & $3.37 \mathrm{E}+14$ \\
0.6 & 422.15 & 3164.1 & 0.133 & $4.14 \mathrm{E}+14$ \\
0.4 & 609.61 & 415.9 & 0.147 & $4.52 \mathrm{E}+14$ \\
0.2 & 833.55 & 4746.2 & 0.176 & 7.004 .71 \\
0.0 & 944.00 & 4944.0 & 0.191 & \\
\hline
\end{tabular}

Assumptions: 1 . The weight fraction of MA: $10.0 \%$

2. $\mathrm{F} / \mathrm{C} / \mathrm{S}=(0.32 / 0.455 / 0.22)$

3. $\phi_{\mathrm{av}}$ for homogeneous loading: $471 \mathrm{E}+14\left(\mathrm{n} / \mathrm{cm}^{2} \mathrm{~s}\right)$ 
Table 3 shows the relations of the total $\mathrm{B} / \mathrm{T}$ rate of MA performed by the inner or outer loading of $\mathrm{B} / \mathrm{T}$ fuel, inventory of MA, ratio of the total $\mathrm{B} / \mathrm{T}$ rate of MA to the inventory of MA, with respect to the normalized radius $\left(\mathrm{R}_{\mathrm{s}} / \mathrm{R}_{\mathrm{o}}\right)$. B/T fuel was loaded into one of the two concentric regions with normalized radius $\left(R_{s} / R_{0}\right)$ in case of heterogeneous loading. The calculation analysis was done for metallic fuel fast $\mathrm{B} / \mathrm{T}$ reactor loaded with $\mathrm{B} / \mathrm{T}$ fuel, fabricated with the composition of $[\mathrm{Pu} / \mathrm{MA} / \mathrm{U} / \mathrm{Zr}]=[0.25 / 0.10 / 0.55 / 0.10](-)$ in weight fraction. The ordinary fuel with no MA, fabricated with $[\mathrm{Pu} / \mathrm{U} / \mathrm{Zr}]=[0.25 / 0.65 / 0.10](-)$ in weight fraction, under the volume fraction of $([\mathrm{F} / \mathrm{C} / \mathrm{S})=(0.325 / 0.455 / 0.220)(-)$, was loaded into the other region i.e. the normal region.

From Table 3, it was understood that the total $\mathrm{B} / \mathrm{T}$ rate of MA for inner loading reached to the maximum value of $944.0 \mathrm{~kg} / \mathrm{y}$ at $\left(\mathrm{R}_{\mathrm{s}} / \mathrm{R}_{\mathrm{o}}\right)=1.0$. Total $\mathrm{B} / \mathrm{T}$ rate of MA for outer loading reached to the maximum value of 944.0 $\mathrm{kg} / \mathrm{y}$, at $\left(\mathrm{R}_{\mathrm{s}} / \mathrm{R}_{\mathrm{o}}\right)=0$. The maximum $\mathrm{B} / \mathrm{T}$ rate can be realized under the full loading of $\mathrm{B} / \mathrm{T}$ fuel, and it means that this limit corresponds to the homogeneous loading of $\mathrm{B} / \mathrm{T}$ fuel. As seen in Table 3, the $\mathrm{B} / \mathrm{T}$ rate for inner loading, and the $\mathrm{B} / \mathrm{T}$ rate for outer loading become nearly equal to each other at about $\left(\mathrm{R}_{\mathrm{s}} / \mathrm{R}_{\mathrm{o}}\right)=0.6$. Thus, the $\mathrm{B} / \mathrm{T}$ rate gained by the inner loading of 0.36 volume fraction of the core may be equal to the $\mathrm{B} / \mathrm{T}$ rate gained by the outer loading of 0.64 volume fraction of the core. Therefore, the inner loading of $\mathrm{B} / \mathrm{T}$ fuel is $1.78(0.64 / 0.36)$ times more effective than the outer loading, because the average neutron flux in the inner region is higher than that in the outer region. This fact can be seen from the ratio of $\{[\mathrm{B} / \mathrm{T}$ rate $]$ MA/[INV]MA $\}$ at $(\mathrm{Rs} / \mathrm{Ro})=0.6$ in Table 3 , that is $1.78(=0.237 / 0.133)$

\section{Effect of MA and $\mathrm{Pu}$ fraction on the $\mathrm{B} / \mathrm{T}$ rate}

The effectiveness of the spectrum shifted neutron flux to the higher side by increasing the blending fraction of MA or $\mathrm{Pu}$ in $\mathrm{B} / \mathrm{T}$ fuel was not so clear in case of the difference of peaks for 6-th and 7-th energy group in Fig. 2(a) to (c). In the following section, the results were evaluated for the case of the concept of the highest $\mathrm{B} / \mathrm{T}$ rate of fast $\mathrm{B} / \mathrm{T}$ reactor, in which $\mathrm{MA}$ was loaded homogeneously with metallic type B/T fuel (U-Pu-MA-Zr). 


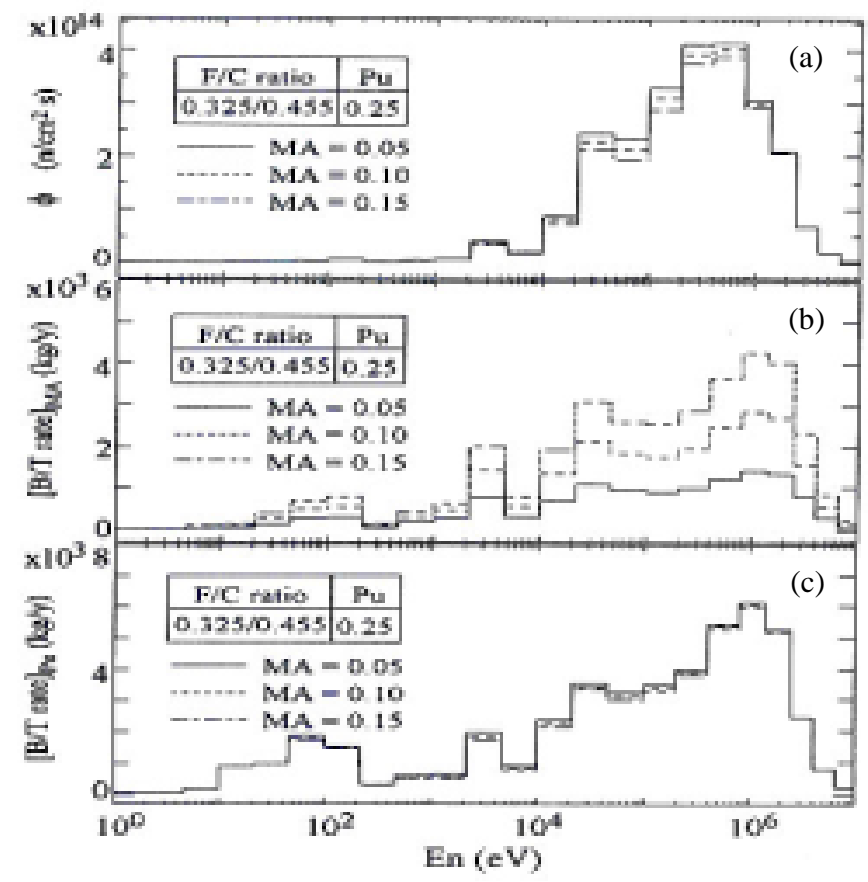

Fig. 3. (a) Relation between neutron flux and neutron energy En, (b) relation between $[\mathrm{B} / \mathrm{T} \text { rate }]_{\mathrm{MA}}$, and $\mathrm{En}$, and (c) relation between $[\mathrm{B} / \mathrm{T} \text { rate }]_{\mathrm{Pu}}$, and En, with the variation of [MA] loaded homogeneously with $(\mathrm{U}-\mathrm{Pu}-\mathrm{MA}-\mathrm{Zr}),[\mathrm{Pu}]=0.25,(\mathrm{~F} / \mathrm{C} / \mathrm{S})=(0.325 / 0.455 / 0.220)$.

The spectrum of neutron flux $\phi$ vs. neutron energy $E_{n}$ is shown in Fig. 3(a). Relation between B/T rate of MA and neutron energy En is shown in Fig. 3(b), and the relation between B/T rate of MA and neutron energy En is shown in Fig. 3(c). Those relation obtained with the variation of MA in metallic fuel, (U-Pu-MA-Zr $\mathrm{r}_{10}$ w\%) with $[\mathrm{Pu}]=0.25(-)$, under the volume fraction of $(\mathrm{F} / \mathrm{C} / \mathrm{S})=(0.325 / 0.455 / 0.220)(-)$.

The similar relation are shown in Fig. 4(a), 4(b), and 4(c), which were obtained with the variation of $[\mathrm{Pu}]$, in metallic fuel U-Pu-MA-Zr $10 \mathrm{w} \%$, with $[\mathrm{MA}]=0.10(-)$, under the volume fraction of $(\mathrm{F} / \mathrm{C} / \mathrm{S})=(0.325 / 0.455 / 0.220)(-)$. Here, $(\mathrm{F} / \mathrm{C})=(0.325 / 0.455)=0.71(-)$, which is the typical value for FBR. 




Fig. 4. (a) Relation between neutron flux and neutron energy En, (b) relation between $[\mathrm{B} / \mathrm{T} \text { rate }]_{\mathrm{MA}}$, and $\mathrm{En}$, and (c) relation between $[\mathrm{B} / \mathrm{T} \text { rate }]_{\mathrm{Pu}}$, and $\mathrm{En}$, with the variation of $[\mathrm{Pu}]$ loaded homogeneously with $(\mathrm{U}-\mathrm{Pu}-\mathrm{MA}-\mathrm{Zr}),[\mathrm{MA}]=0.10,(\mathrm{~F} / \mathrm{C} / \mathrm{S})=(0.325 / 0.455 / 0.220)$.

The spectrum of neutron flux in Fig. 3(a) and Fig. 4(a) had three peaks, i.e. $0.4-0.8 \mathrm{MeV}$ (6th group), 21.5-46.5 keV (10th group) and 2.15-4.65 keV (13th group). The spectrum shift of neutron flux could not be seen clearly with the variation of weight fraction, such as $[\mathrm{MA}]=(0.05-0.15)(-)$, or $[\mathrm{Pu}]=(0.25-0.30)(-)$. However, the results showed that the B/T rate of MA and Pu (see Fig. 3(b), (c) and Fig. 4(b), (c)) had four different peaks, such as 0.8-1.4 MeV (5th group), 21.5-46.5 keV (10th group), 2.15-4.65 keV (13th group), and 100-215 eV (17th group). The highest spectrum peak of $\mathrm{B} / \mathrm{T}$ rate was $0.8-1.4 \mathrm{MeV}$ (5th group), while the highest spectrum peaks of neutron flux was 0.8-1.4 MeV (6th group). The spectrum shift of B/T rate could not be seen clearly with variation of weight fraction of $\mathrm{MA}$ or $\mathrm{Pu}$. The role of neutron spectrum shift higher than $1 \mathrm{MeV}$ may be important in $\mathrm{B} / \mathrm{T}$ treatment and in design of $\mathrm{B} / \mathrm{T}$ reactor. $\mathrm{B} / \mathrm{T}$ rate of $\mathrm{MA}$ was increased proportionally with the weight fraction of $\mathrm{MA}$, but $\mathrm{B} / \mathrm{T}$ rate of $\mathrm{Pu}$ did not changed so much with the variation of weight fraction of $\mathrm{Pu}$, because the total change of macroscopic fission cross section of MA is far larger than the total macroscopic fission cross section of $\mathrm{Pu}$.

It must be pointed out that the spectrum shift of neutron flux to the higher energy side producing high rate of fission of MA, and it makes the neutron flux low, because the total power of $\mathrm{B} / \mathrm{T}$ reactor was kept constant. 
The spectrum shift of neutron flux was similar to the neutron flux in a core, loaded with fuel of high fissile density or high-enriched uranium. Therefore, the average neutron flux of B/T reactor change lower In case of the spectrum shift of neutron flux under the constant power generation, as seen in Table 1. The spectrum shift of neutron flux can be understood by the sink-source term of neutron in the multi-group diffusion equations.

Generally, it is well known that heavier mass and/or heavier isotope of MA and Pu produces the higher value of prompt neutron at high energy, so the higher blending fraction of MA or Pu will support the spectrum shift of neutron flux to the higher energy region, but according to the results obtained the phenomena could be seen only a slight extent.

\section{Effect of $\mathrm{F} / \mathrm{C}$ ratio on the $\mathrm{B} / \mathrm{T}$ rate}

Neutron spectrum could be shifted by the change of F/C ratio, i.e. the volume ratio of fuel to coolant, due to the change in neutron absorption to fuel, coolant and structure. Relation between neutron flux vs. neutron energy En is shown in Fig. 5(a).

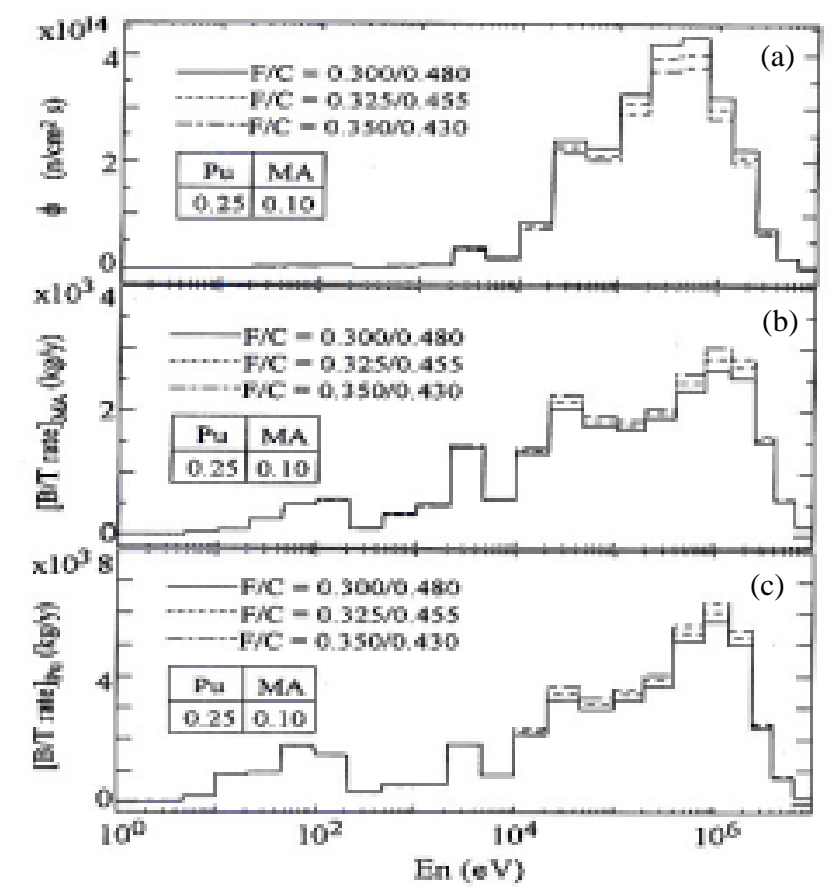

Fig. 5. (a) Relation between neutron flux and neutron energy En, (b) relation between $[\mathrm{B} / \mathrm{T} \text { rate }]_{\mathrm{MA}}$, and $\mathrm{En}$, and (c) relation between $[\mathrm{B} / \mathrm{T}$ rate $]_{\mathrm{Pu}}$, and $\mathrm{En}$, with the variation of $(\mathrm{F} / \mathrm{C})$ ratio loaded homogeneously with (U-Pu-MA-Zr), $[\mathrm{Pu}]=0.25,[\mathrm{MA}]=0.10$, $(\mathrm{F} / \mathrm{C} / \mathrm{S})=(0.325 / 0.455 / 0.220)$. 
The relation between $\mathrm{B} / \mathrm{T}$ rate of MA and neutron energy En is shown in Fig. 5(b), and the relation between B/T rate of Pu and neutron energy En is shown in Fig. 5(c). Those relation were obtained with the variation of F/C ratio for metallic fuel of U-Pu-MA-Zr $10 \mathrm{w} \%$ with $[\mathrm{Pu}]=0.25(-)$, and [MA] $=(0.10)(-)$ under the volume fraction of $(\mathrm{F} / \mathrm{C} / \mathrm{S})=(0.300 / 0.480 / 0.220)(-)$, $(0.325 / 0.455 / 0.220)(-)$ to $(0.350 / 0.430 / 0.220)(-)$. The neutron fluxes decrease with increasing the $\mathrm{F} / \mathrm{C}$ ratio, because the direct increase of the atomic density of fissile material increased.

If the macroscopic cross section $\left(\sigma_{\mathrm{i}} \mathrm{N}_{\mathrm{i}}\right)$ of the fuel, coolant and structure in the reactor core are defined by $\Sigma_{\mathrm{f}}, \Sigma_{\mathrm{c}}$ and $\Sigma_{\mathrm{s}}$ then $\Sigma_{\mathrm{f}} \gg \Sigma_{\mathrm{c}}, \Sigma_{\mathrm{s}}$ holds, and $\left(\mathrm{F} \Sigma_{\mathrm{f}}>>\mathrm{C} \Sigma_{\mathrm{c}}, \mathrm{S} \Sigma_{\mathrm{s}}\right)$ holds, too. Then, the neutron flux, obtained by the diffusion equation of neutron, cannot change so much in space and in energy, because the neutron absorption fraction in the core element $\left(\mathrm{F} \Sigma_{\mathrm{f}}, \mathrm{C} \Sigma_{\mathrm{c}}\right.$, $S \Sigma_{\mathrm{s}}$ ) could not change in a drastic way even if the $(\mathrm{F} / \mathrm{C})$ ratio changed. Therefore, it is not so effective to make the neutron spectrum harden by the change of $(\mathrm{F} / \mathrm{C})$ ratio under the condition of $\left(\mathrm{F} \Sigma_{\mathrm{f}}>\mathrm{C} \Sigma_{\mathrm{c}}, \mathrm{S} \Sigma_{\mathrm{s}}\right)$ because the neutron absorption to coolant or structure is always smaller than the absorption to fuel.

\section{Total $\mathrm{B} / \mathrm{T}$ rate with $[\mathrm{MA}],[\mathrm{Pu}]$, and $(\mathrm{F} / \mathrm{C})$ ratio}

Finally, the integrated consideration was done to get the total $\mathrm{B} / \mathrm{T}$ rate of $[\mathrm{MA}]$, i.e. $[\mathrm{B} / \mathrm{T}$ rate]MA defined by the Eqs. (9) or (12), based on the spectrum change of B/T rate in Fig. 3(b), 3(c), 4(b), 4(c), 5(b), and Fig. 5(c).

The relation of the integrated $\mathrm{B} / \mathrm{T}$ rate of $\mathrm{MA}, \mathrm{Pu}$, and $(\mathrm{MA}+\mathrm{Pu})$ with respect to the blending fraction of MA, [MA], is shown in Fig. 6. Furthermore, the relation of the integrated $\mathrm{B} / \mathrm{T}$ rate of $\mathrm{MA}, \mathrm{Pu}$, and $\mathrm{MA}+$ $\mathrm{Pu}$ ) with respect to the blending fraction of $\mathrm{Pu},[\mathrm{Pu}]$, is shown in Fig. 7. The relation were evaluated for metallic fuel, $\left(\mathrm{U}-\mathrm{Pu}-\mathrm{MA}-\mathrm{Zr}_{10 \mathrm{w}}\right.$ ), under $(\mathrm{F} / \mathrm{C} / \mathrm{S})=$ $(0.325 / 0.455 / 0.220)(-),(\mathrm{F} / \mathrm{C})=0.71(-),[\mathrm{Pu}]=0.25(-)$, and $[\mathrm{MA}]=(0.10)(-)$ in weight fraction.

$[\mathrm{B} / \mathrm{T} \text { rate }]_{\mathrm{MA}}$ in Fig. 6 increased proportionally with increasing [MA], but at the same time $[\mathrm{B} / \mathrm{T} \text { rate }]_{\mathrm{Pu}}$ decreased slightly due to the decreasing of neutron flux under the condition of the constant power generation. [B/T rate $]_{\mathrm{Pu}}$ in Fig. 7 increased slightly with increasing $[\mathrm{Pu}]$, but $[\mathrm{B} / \mathrm{T} \text { rate }]_{\mathrm{MA}}$ decreased slightly with increasing $[\mathrm{Pu}]$, due to decreasing of neutron flux. The properties of MA in $\mathrm{B} / \mathrm{T}$ treatment were different from those of $\mathrm{Pu}$. 


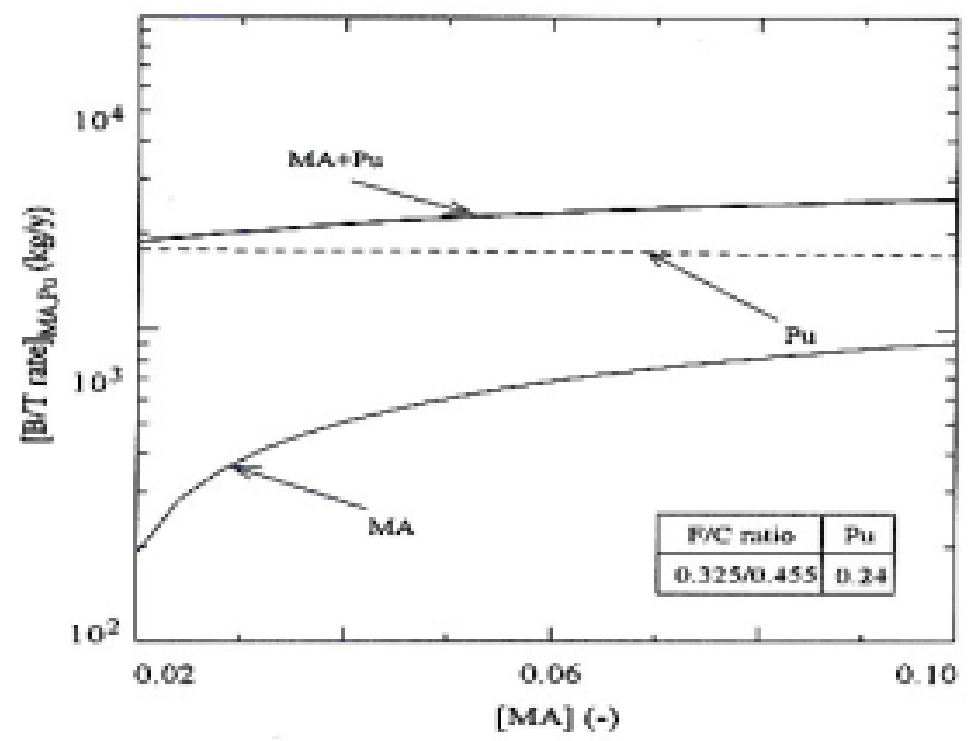

Fig. 6. Relation between total $\mathrm{B} / \mathrm{T}$ rate of $\mathrm{MA}, \mathrm{Pu}$ and $\mathrm{MA}+\mathrm{Pu}$ with respect to $[\mathrm{MA}]$, loaded homogeneously with (U-Pu-MA-Zr), $[\mathrm{Pu}]=0.25$, $(\mathrm{F} / \mathrm{C} / \mathrm{S})=(0.325 / 0.455 / 0.220)$.

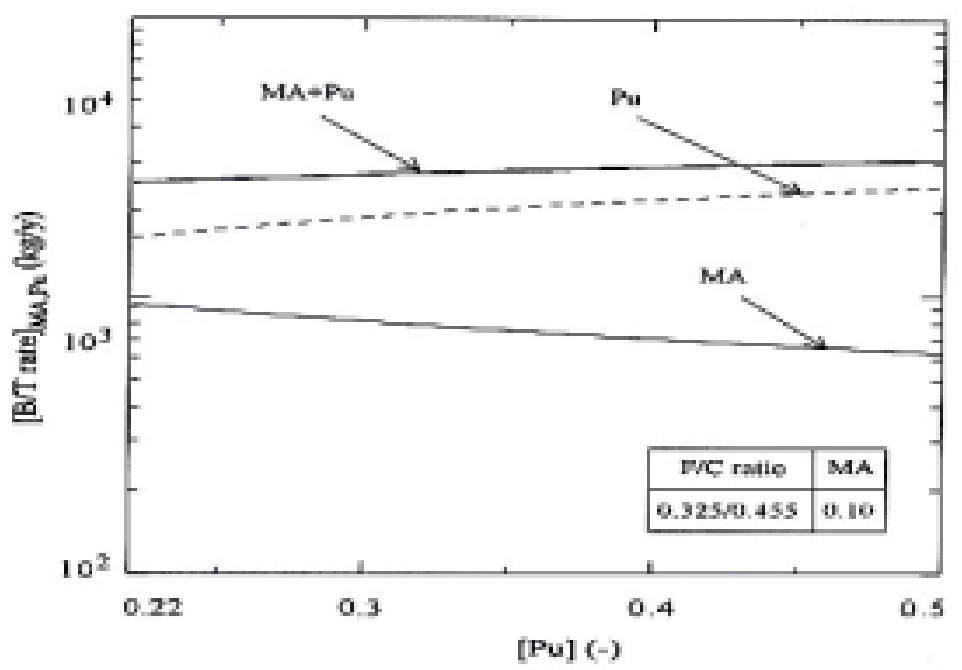

Fig. 7. Relation between total $\mathrm{B} / \mathrm{T}$ rate of $\mathrm{MA}, \mathrm{Pu}$ and $\mathrm{MA}+\mathrm{Pu}$ with respect to $[\mathrm{Pu}]$, loaded homogeneously with (U-Pu-MA-Zr), $[\mathrm{MA}]=0.10$, $(\mathrm{F} / \mathrm{C} / \mathrm{S})=(0.325 / 0.455 / 0.220)$.

The relation of the integrated $\mathrm{B} / \mathrm{T}$ rate of $\mathrm{MA}, \mathrm{Pu}$, and $(\mathrm{MA}+\mathrm{Pu})$ at different $(\mathrm{F} / \mathrm{C})$ ratio for metallic fuel reactor was evaluated for $[\mathrm{Pu}]=0.25(-)$ and $[\mathrm{MA}]=(0.10)(-)$ in weight fraction, the variation of $(\mathrm{F} / \mathrm{C})$ ratio, such as 
$(\mathrm{F} / \mathrm{C})=0.30(-)$ under the volume fraction of $(\mathrm{F} / \mathrm{C} / \mathrm{S})=(0.260 / 0.520 / 0.220)$ (-) metallic fuel, (U-Pu-MA-Z $\mathrm{r}_{10}$ w\%), under, $(\mathrm{F} / \mathrm{C})=0.71(-)$, where $\mathrm{F}+\mathrm{C}+\mathrm{S}=1$. In this study, $\mathrm{S}$ was fixed at 0.22 , referred to fast reactor [1], thus $\mathrm{F}+\mathrm{C}=0.78$ or $(\mathrm{F} / \mathrm{C})=\mathrm{F} /(0.78-\mathrm{F})$ holds.

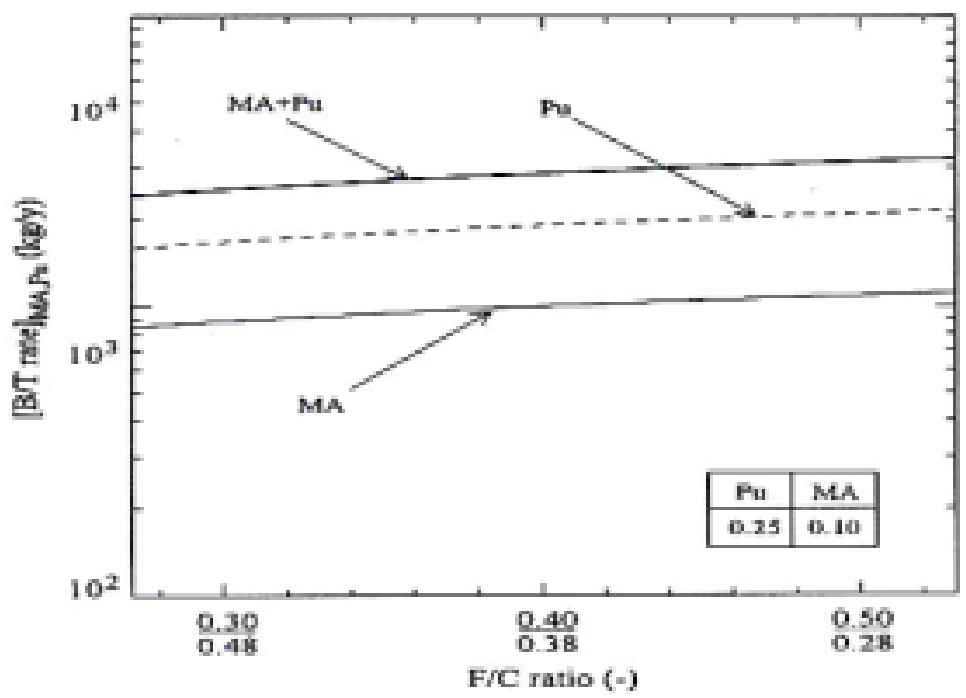

Fig. 8. Relation between total $\mathrm{B} / \mathrm{T}$ rate of $\mathrm{MA}, \mathrm{Pu}$ and $\mathrm{MA}+\mathrm{Pu}$ with respect to (F/C) ratio, loaded homogeneously with (U-Pu-MA-Zr), $[\mathrm{Pu}]=0.25$ and $[\mathrm{MA}]=0.10$.

According to Fig. $8,[\mathrm{~B} / \mathrm{T} \text { rate }]_{\mathrm{MA}}$ increased slightly with change of $\mathrm{F} / \mathrm{C}$ ratio from 0.3 to 0.5 . The change of $(\mathrm{F} / \mathrm{C})$ ratio cannot be essential to bring the neutron spectrum shift, as seen in Fig. 5(a) to 5(c). The $\left\{[\mathrm{B} / \mathrm{T} \text { rate }]_{\mathrm{MA}}\right.$ $\left./[\mathrm{P}]_{\mathrm{MA}}\right\}$ is an important factor to judge the efficiency of $\mathrm{B} / \mathrm{T}$ treatment, because $[\mathrm{B} / \mathrm{T} \text { rate }]_{\mathrm{MA}}$ should be far larger than the production rate of MA, $[\mathrm{P}]_{\mathrm{MA}}$. According to the results,

$$
\begin{array}{llll}
\{[\mathrm{B} / \mathrm{T} \text { rate }] /[\mathrm{P}]\}_{\mathrm{MA}}=8.0(-) & \text { at } & & {[\mathrm{MA}]=0.10(-)} \\
\{[\mathrm{B} / \mathrm{T} \text { rate }] /[\mathrm{P}]\}_{\mathrm{MA}}=17.5(-) & \text { at } & {[\mathrm{MA}]=0.20(-)}
\end{array}
$$

under $[\mathrm{Pu}]=0.25(-)$ and $(\mathrm{F} / \mathrm{C})=0.325 / 0.455)=0.71(-)$. Then, the higher blending fraction of MA In $\mathrm{B} / \mathrm{T}$ fuel is better to perform the effective $\mathrm{B} / \mathrm{T}$ treatment.

It may be important to get the high conversion ratio, too, i.e.

$$
=[\mathrm{B} / \mathrm{T} \text { rate }] /[\mathrm{MA}]_{\text {in }}=1-\left\{[\mathrm{MA} \text { remain }] /[\mathrm{MA}]_{\text {in }}\right\}
$$

which can be attained in $\mathrm{B} / \mathrm{T}$ treatment for one cycle period or one year, and in this study varies with the reaction time in the reactor core, and $\varepsilon=0.27$ to 0.35 for one year depending on the reactor condition. 


\section{CONCLUSIONS}

1. According to the results, spectrum shift of neutron flux to higher energy side has a potential significance to increase the $\mathrm{B} / \mathrm{T}$ rate of MA and/or $\mathrm{Pu}$ by fast $\mathrm{B} / \mathrm{T}$ reactor. The spectrum shift could be effectively performed by the selection of chemical form of fuel and/or coolant. The slightly effects through the adjustment of fuel material with high blending fraction of MA or $\mathrm{Pu}$, due to the higher production value of the prompt neutron in the higher energy region. The variation of $(\mathrm{F} / \mathrm{C})$ ratio seemed to be noneffective to shift the neutron spectrum for a practical fast reactor.

2. The sum of the integrated $\mathrm{B} / \mathrm{T}$ rate, i.e. $[\mathrm{B} / \mathrm{T} \text { rate }]_{\mathrm{M}} \mathrm{A}+[\mathrm{B} / \mathrm{T} \text { rate }]_{\mathrm{Pu}}$, would be kept nearly constant under the critical condition of the reactor, if the sum of the loading inventory of $\mathrm{MA}$ and $\mathrm{Pu}$ in the reactor core is nearly constant.

3. The homogeneous loading of $\mathrm{B} / \mathrm{T}$ fuel was a better selection for obtaining the $\mathrm{B} / \mathrm{T}$ rate by fast $\mathrm{B} / \mathrm{T}$ reactor, rather than the concentric inner or outer loading of $\mathrm{B} / \mathrm{T}$ fuel.

\section{ACKNOWLEDGMENT}

The authors would like to express their gratitude to Prof. Dr. Marsongkohadi, Prof. Dr. Zaki Suud, and Dr. As Natio Lasman for supporting and suggesting our work in order to finish the manuscript to be submitted to Atom Indonesia. The author also acknowledge the referee to their constructive criticism for improving this manuscript.

\section{Nomenclature}

$[\mathrm{B} / \mathrm{T}$ rate $]$

$[\mathrm{B} / \mathrm{T} \text { rate }]_{\mathrm{av}}$

$[\mathrm{B} / \mathrm{T} \text { rate }]_{\mathrm{t}}$

[Cp]

En

(F)

$(\mathrm{F} / \mathrm{C} / \mathrm{S})$

$\mathrm{f}_{\mathrm{ik}}$

[INV]

$\mathrm{i}_{\mathrm{ij}}$

$\mathrm{M}$

[MA]

$\mathrm{M}_{\mathrm{i}}$

$\mathrm{N}_{\mathrm{A}}$
$\mathrm{B} / \mathrm{T}$ rate at time $\mathrm{t}$, defined by Eq. (12)

time average $\mathrm{B} / \mathrm{T}$ rate, defined by Eq. (13)

$(\mathrm{kg} / \mathrm{y})$

$(\mathrm{kg} / \mathrm{y})$

integrated $\mathrm{B} / \mathrm{T}$ rate derived from multi-group mode, defined by Eq. (13)

B/T capacity of reactor for HLW

$(\mathrm{kg} / \mathrm{y})$

$(\mathrm{kg})$

$(\mathrm{eV})$

neutron energy

$(-)$

$(-)$

(-)

(kg)

( $\mathrm{gr} / \mathrm{mol})$

(mole/mol) 


\begin{tabular}{|c|c|c|}
\hline $\mathrm{N}_{\mathrm{BT}}$ & number of isotope of MA and/or LLFPs Iin B/T fu & $(-)$ \\
\hline $\mathrm{N}_{\mathrm{g}}$ & number of neutron group & $(-)$ \\
\hline $\mathrm{N}_{\mathrm{i}}$ & atomic density of nuclide i & $\left(\right.$ atom $\left./ \mathrm{cm}^{3}\right)$ \\
\hline $\mathrm{N}_{\mathrm{i}}^{\mathrm{IBT}}$ & $\begin{array}{l}\text { atomic density of i produced by } \mathrm{MA} \text { in } \mathrm{B} / \mathrm{T} \text { fuel } \\
\text { in the inner region }\end{array}$ & $\left(\operatorname{atom} / \mathrm{cm}^{3}\right)$ \\
\hline $\mathrm{N}_{\mathrm{i}}^{\mathrm{IF}}$ & $\begin{array}{l}\text { atomic density of } i \text { produced by fuel in the } \\
\text { Inner region }\end{array}$ & $\left(\right.$ atom $\left./ \mathrm{cm}^{3}\right)$ \\
\hline $\mathrm{N}_{\mathrm{i}}^{\mathrm{OBT}}$ & $\begin{array}{l}\text { atomic density of i produced by } \mathrm{MA} \text { in } \mathrm{B} / \mathrm{T} \text { fuel } \\
\text { in the outer region }\end{array}$ & $\left(\right.$ atom $\left./ \mathrm{cm}^{3}\right)$ \\
\hline $\mathrm{N}_{\mathrm{i}}^{\mathrm{OF}}$ & $\begin{array}{l}\text { atomic density of i produced by fuel In the } \\
\text { outer region }\end{array}$ & $\left(\right.$ atom $\left./ \mathrm{cm}^{3}\right)$ \\
\hline$[\mathrm{P}]$ & production rate of MA from fuel component & $(\mathrm{kg} / \mathrm{y})$ \\
\hline $\mathrm{R}_{\mathrm{s}}, \mathrm{R}_{\mathrm{o}}$ & radius of (B/T region, reactor core) & (cm) \\
\hline$[\mathrm{Pu}],[\mathrm{U}]$ & weight fraction of $(\mathrm{Pu}, \mathrm{U})$ in $\mathrm{B} / \mathrm{T}$ fuel & $(-)$ \\
\hline$\Delta u^{g}$ & lethargy for energy width of group-g & $(-)$ \\
\hline$\beta$ & blending ratio based on atomic number density & $(-)$ \\
\hline$\varepsilon$ & $\begin{array}{l}\text { efficiency of } \mathrm{B} / \mathrm{T} \text { treatment, } \\
\left(=\left\{[\mathrm{B} / \mathrm{T} \text { rate }] /\left[\mathrm{MA}_{\mathrm{in}}\right]\right\}, \text { or } 1-\left\{\left[\mathrm{MA}_{\text {remain }}\right] /\left[\mathrm{MA}_{\mathrm{i}}\right]\right\}\right.\end{array}$ & (1) \\
\hline$\phi^{\mathrm{g}}(\mathrm{r})$ & local neutron flux of group-g & $\left(\mathrm{n} / \mathrm{cm}^{2} \mathrm{~s}\right)$ \\
\hline$\phi^{\mathrm{g}}$ & average neutron flux , defined by Eq. (6) and (7) & $\left(\mathrm{n} / \mathrm{cm}^{2} \mathrm{~s}\right)$ \\
\hline$\chi^{\mathrm{g}}$ & fraction of neutron produced in group-g by fission & $(-)$ \\
\hline$\eta_{\mathrm{i}}$ & fission yield of nuclide i & $(-)$ \\
\hline$\sigma_{\mathrm{f}}^{\mathrm{g}}$ & fission cross section of group-g & (barn) \\
\hline$\sigma_{\mathrm{a}}^{\mathrm{g}}$ & $\begin{array}{l}\text { total absorption cross section of group-g } \\
\left.\left(=\sigma_{(\mathrm{n}, \mathrm{f})}^{\mathrm{g}}+\sigma_{(\mathrm{n}, \gamma)}{ }^{\mathrm{g}}+\sigma_{(\mathrm{n}, \alpha)}{ }^{\mathrm{g}}+\sigma_{(\mathrm{n}, \beta)}\right)^{\mathrm{g}}\right)\end{array}$ & (barn) \\
\hline$\tau$ & period of recycle & (y) \\
\hline
\end{tabular}

\section{Abbreviation}

$\mathrm{B} / \mathrm{T}$

burning and/or transmutation

LLFPs long-lived fission products

MA minor actinide (Np, Am, Cm, Bk, Cf, Es)

MA*) U and TRU included In HLW, i.e. (Np, Am, Cm, and $\mathrm{U} \& \mathrm{Pu}$ )

P-T partitioning and transmutation

TRU transuranics, (Pu and MA)

$\mathrm{U} \& \mathrm{Pu} \quad \mathrm{U}$ and $\mathrm{Pu}$ in HLW, unrecovered at reprocessing

HM heavy metal 


\section{REFERENCES}

1. MARSODI, MULYANTO, KITAMOTO A., "Concept and Optimization of burning and Transmutation Reactor in Nuclear Fuel Cycle System", Proceedings of 7-th International Conference on Emerging Nuclear Energy Systems, ICENES'93, Makuhari, Japan, 478-482 (1993).

2. TAKASHITA H., TAKAHASHI H., HARADA H., RANSON A., TAKAHASHI T., SASAO N., " Study on Transmutation of MA and FPs in Prototype Fast Reactor with Mixed-Oxide Fuel", Proceedings of 7-th International Conference on Emerging Nuclear Energy Systems, ICENES‘93, Makuhari, Japan, , 473-477. (1993).

3. MUKAEYAMA T., YOSHIDA H., GUNJI Y., “ Minor Actinide Transmutation using Minor Actinide Burner Reactors”, Proceeding of International Conference on Fast Reactor and Related Fuel Cycles, Kyoto, Japan, IV, 19.6 (1991).

4. TAKANO, H., AKIE H. HONDA M., HIRAOKA T., "A Concept of Self-Completed Fuel Cycle Based on Nitride Fuel Lead Cooled Fast Reactor", Proceeding of 7th International Conference on Emerging Nuclear Energy System, ICENES ‘93, 308-115 (1993).

5. THOMPSON M.L., QUIN J.E., "The ALMR System's Missions for Transmuting Waste into Energy", Proceedings of International Conference and Technology Exhibition on Future Nuclear System; Emerging Fuel Cycles and Wastes Disposal Options, GLOBAL'93, Seattle, USA, 110-117 (1993).

6. Advanced Reactor Design Team in JAERI: "Analysis of Reactor Characteristics for Advanced Burning Reactor", JAERI-M 89-072, (1988).

7. WAKABAYASHI T., "Transmutation Characteristics of MA and LLFP in Fast Reactor", Proceeding of The Second Fujihara International Seminar for Advanced Nuclear Energy Systems Toward Zero Release of Radioactive Wastes", Susono, Japan, November 6-9, (2000).

8. BONDARENKO I.I., "Group Constants for Nuclear Reactor Calculation”, Consult. Bureau, New York, (1964).

9. Mc. LANE, V., C.L. DUNFORD, P.F. ROSE, "Neutron Cross section", Academic Press, 2 (988).

10. BARRE J.Y., BOUCHARD J., "French R\&D Strategy for the Bach End of the Fuel Cycle", Proceedings of Intl. Conference and Tech. Exhibition on Future Nuclear System; Emerging Fuel Cycles and Wastes Disposal Options, GLOBAL'93, Seattle, USA, 27-32 (1993). 
11. SANDA T., FUJIMURA K., KOBAYASHI K., KAWASHIMA K., YAMAWAKI M., KONASHI K., " Fast Reactor Core Concept for MA Transmutation using Hydride Fuel Targets", Proceedings of International Conference and Technology Exhibition on Future Nuclear System; Challenge Towards Second Nuclear Era with Advanced Fuel Cycles, GLOBAL'97, Seattle, USA, 326-331 (1997).

12 OKOYAMA K., TAKEDA T., HOROKAWA N., "Comparison of Minor Actinide Incineration in Advanced Thermal and Fast Reactors", Proceedings of International Conference and Technology Exhibition on Future Nuclear System; Challenge Towards Second Nuclear Era with Advanced Fuel Cycles, GLOBAL‘97, Seattle, USA, 230-235 (1997). 